\title{
UPAYA MENINGKATKAN KETUNTASAN BELAJAR MEMASTIKAN KEBUTUHAN AKAN DOKUMEN MELALUI PENERAPAN PEMBELAJARAN KOOPRATIF MODEL STUDENT TEAMS ACHIEVEMENT DIVISIONS (STAD) PADA SISWA KELAS XII APk-1 SMK NEGERI 1 MAGETAN PADA TAHUN PELAJARAN 2010/2011
}

\author{
Arum Yuliani \\ SMK Negeri 1 Magetan \\ roem.nugraha@gmail.com
}

\begin{abstract}
One of the topics of discussion among teachers, especially in the Office Administration Expertise Program of SMK Negeri 1 Magetan is the problem of managing learning by grouping students who sometimes experience obstacles and do not carry out as expected. This resulted in the results of group work becoming less than optimal and only a small percentage of students understood the group assignment material. As a result, when there is a test, there are still many students who get less grades from KKM or have not yet finished learning and classical learning completeness has not been achieved. This research is planned in three cycles. Each cycle consists of four stages, namely (1) planning, (2) implementation, (3) observation, and (4) reflection. The results of the study were obtained (1) The application of STAD model cooperative learning can improve learning completeness to ensure the need for documents in class XII APk-1 SMK 1 Magetan in the academic year 2010/2011, (2) Application of STAD model cooperative learning can improve group learning activities in ensuring the need for documents in class XII APk-1 students at SMK Negeri 1 Magetan in the academic year 2010/2011, and (3) the application of STAD model cooperative learning is fun and can encourage students of class XII APK-1 at SMK Negeri 1 Magetan in the 2010 school year / 2011 to diligently study on basic competencies Ensuring the Need for Documents.
\end{abstract}

Keywords: Mastery learning, STAD

\begin{abstract}
Abstrak
Salah satu yang menjadi bahan diskusi di kalangan guru, khususnya di lingkungan Program Keahlian Administrasi Perkantoran SMK Negeri 1 Magetan adalah masalah pengelolaan pembelajaran dengan mengelompokkan siswa yang terkadang mengalami kendala dan tidak terlaksana sesuai dengan harapan. Hal itu mengakibatkan hasil pekerjaan kelompok menjadi kurang maksimal dan hanya sebagian kecil saja siswa yang memahami materi tugas kelompok. Akibatnya ketika diadakan tes, masih banyak siswa yang memperoleh nilai kurang dari KKM atau belum tuntas belajar dan ketuntasan belajar secara klasikal belum tercapai. Penelitian ini direncanakan dalam tiga siklus. Setiap siklusnya terdiri dari empat tahap yaitu (1) perencanaan, (2) pelaksanaan, (3) pengamatan, dan (4) refleksi. Hasil penelitian diperoleh (1) Penerapan pembelajaran kooperatif model STAD dapat meningkatkan ketuntasan belajar memastikan kebutuhan akan dokumen pada siswa kelas XII APk-1 SMK Negeri 1 Magetan pada tahun pelajaran 2010/2011, (2) Penerapan pembelajaran kooperatif model STAD dapat meningkatkan aktivitas belajar kelompok dalam memastikan kebutuhan akan dokumen pada siswa kelas XII APk-1 SMK Negeri 1 Magetan pada tahun pelajaran 2010/2011, dan (3) Penerapan pembelajaran kooperatif model STAD menyenangkan dan dapat mendorong siswa kelas XII APk-1 SMK Negeri 1 Magetan pada tahun pelajaran 2010/2011 untuk rajin belajar pada kompetensi dasar Memastikan Kebutuhan akan Dokumen.
\end{abstract}

Kata Kunci: Ketuntasan Belajar; STAD 


\section{PENDAHULUAN}

Salah satu yang menjadi bahan diskusi di kalangan guru, khususnya di lingkungan Program Keahlian Administrasi Perkantoran SMK Negeri 1 Magetan adalah masalah pengelolaan pembelajaran dengan mengelompokkan siswa yang terkadang mengalami kendala dan tidak terlaksana sesuai dengan harapan. Pengelompokan siswa tersebut, terkadang menimbulkan permasalahan bagi guru, sebagaimana yang dialami oleh peneliti ketika melaksanakan pembelajaran dengan belajar berkelompok di kelas XII APk-1. Ketika guru memberikan tugas kelompok, ternyata siswa tidak dapat bekerja sama secara efektif dalam kelompok. Siswa cenderung mengerjakan tugas dengan tidak bersungguh-sungguh, memboroskan waktu dengan berbicara di luar materi pelajaran, bergurau, bahkan beberapa siswa diam saja.

Dari data hasil pengamatan yang dilakukan di awal memasuki tahun ajaran baru 2010/2011 yaitu pada hari Kamis tanggal 29 juli 2010 saat jam pembelajaran dengan materi tentang ergonomi dan sumber daya alam dan energi pada kompetensi dasar Menggunakan Praktik Kerja yang Aman di kelas XII APk-1, ketika guru memberi tugas kelompok dengan setiap kelompok beranggotakan 5 orang, maka yang aktif untuk mengerjakan tugas kelompok hanya sekitar 2 orang. Bahkan ada juga kelompok yang didominasi oleh satu orang saja. Hal itu mengakibatkan hasil pekerjaan kelompok menjadi kurang maksimal dan hanya sebagian kecil saja siswa yang memahami materi tugas kelompok. Akibatnya ketika diadakan tes, masih banyak siswa yang memperoleh nilai kurang dari KKM atau belum tuntas belajar dan ketuntasan belajar secara klasikal belum tercapai. Dari jumlah 35 siswa yang mengikuti tes, yang mendapat nilai $\geq 75$ sesuai dengan KKM (KTSP-SMK Negeri 1 Magetan: 2006) hanya 11 siswa atau sekitar $31.43 \%$, jauh dari ketentuan yaitu 85 $\%$. Selain permasalahan yang disebabkan oleh siswa, peneliti mengakui bahwa guru juga mempunyai kontribusi terhadap timbulnya permasalahan belajar kelompok tersebut. Misalnya, guru kurang telaten di dalam memberikan bimbingan kepada siswa ketika sedang bekerja dalam kelompok, guru kurang memotivasi siswa, guru tidak melakukan penilaian terhadap aktivitas individu dalam kelompok, guru bersikap kurang tegas, atau justru guru meninggalkan kelas pada saat jam pembelajaran.

Johnson dan Bany dalam Madjid (2008:117) mengidentifikasi tujuh masalah kelompok dalam pengelolaan kelas, yaitu (1) kurangnya kesatuan, (2) ketidaktaatan terhadap standar tindakan dan prosedur kerja, (3) reaksi negative terhadap pribadi anggota, (4) pengakuan kelas terhadap kelakuan guru, (5) kecenderungan adanya gangguan, kemacetan pekerjaan, dan kelakuan yang dibuat-buat, (6) ketidakmampuan untuk menyesuaikan diri dengan perubahan lingkungan, dan (7) semangat juang yang rendah dan adanya sikap bermusuhan. Menurut $\mathrm{M}$. Entang dan T. Raka Joni dalam Madjid (2008: 114) tindakan pengelompokan siswa yang dilakukan guru akan efektif apabila ia dapat mengidentifikasi dengan tepat hakikat masalah yang sedang dihadapi, sehingga pada gilirannya ia dapat memilih strategi penanggulangan yang tepat pula. Pendapat lain mengemukakan bahwa langkah-langkah yang bisa ditempuh adalah mengenal alternatif pengelolaan berupa berbagai pendekatan dalam manajemen kelas. Guru hendaknya berusaha menggunakan pendekatan manajemen yang dianggap tepat untuk mengatasi suatu situasi atau menggantinya dengan pendekatan yang dipilihnya (Madjid, 2008:121).

Merujuk beberapa pendapat yang dikemukakan di atas, serta membaca beberapa referensi tentang pengelolaan kelas dengan model pembelajaran kooperatif, penulis tertarik dengan pembelajaran kooperatif model Student Teams Achievement Divisions (STAD 
yang dikembangkan oleh Robert Slavin dan kawan-kawan dari Universitas John Hopkins (Sugiyanto, 2007: 14) karena pada metode ini siswa dikondisikan untuk bekerja secara berkelompok dan antar siswa, terutama yang memahami materi tugas kelompoknya bisa saling membantu untuk dapat menguasai materi pelajaran. Bila siswa menginginkan agar kelompok memperoleh penghargaan, maka mereka harus membantu kelompoknya untuk melakukan yang terbaik, bahwa belajar merupakan sesuatu yang menyenangkan, penting dan berharga. Selain itu dengan pembelajaran kooperatif model STAD dapat menumbuhkan jiwa berkompetisi pada diri siswa dan siswa menjadi bersemangat dalam kegiatan pembelajaran.

\section{A. Ketuntasan Belajar}

Tujuan proses mengajar - belajar secara ideal adalah agar bahan yang dipelajari dikuasai sepenuhnya oleh murid. Ini disebut 'mastery learning" atau belajar tuntas, artinya penguasaan penuh (Nasution,2003: 36). Belajar tuntas merupakan strategi pelajaran yang dapat dilaksanakan di dalm kelas, dengan asumsi bahwa di dalam kondisi yang tepat semua peserta didik akan mampu belajar dengan baik dan memperoleh hasil belajar secara maksimal terhadap seluruh bahan yang dipelajari (Mulyasa, 2006: 53).

Ketuntasan belajar merupakan pencapaian hasil belajar yang ditetapkan dengan ukuran atau tingkat pencapaian kompetensi yang memadai dan dapat dipertanggungjawabkan sebagai prasyarat penguasaan kompetensi lebih lanjut (Depdiknas, Buku 3, 2004:16). Sesuai dengan ketentuan dalam Kurikulum Berbasis Kompetensi (KBK), siswa tuntas belajar bila telah $75 \%$ menguasai kompetensi atau sekurang-kurangnya harus mencapai skor minimal 75 (Sunoto, 2002 : 93). Dalam pola ini ditentukan bahwa seorang siswa yang mempelajari unit satuan pembelajaran tertentu dapat berpindah ke unit satuan pembelajaran berikutnya jika siswa yang bersangkutan telah menguasai sekurangkurangnya $75 \%$ dari kompetensi dasar yang telah ditetapkan (Depdiknas, 2004: 14).
Salah satu prinsip penilaian pada kurikulum berbasis kompetensi adalah menggunakan acuan kriteria, yakni menggunakan kriteria tertentu dalam menentukan kelulusan peserta didik. Kriteria paling rendah untuk menyatakan peserta didik mencapai ketuntasan dinamakan Kriteria Ketuntasan Minimal (KKM). Sesuai dengan kurikulum yang berlaku di SMK Negeri 1 Magetan, maka KKM yang ditetapkan untuk kompetensi dasar Memastikan Kebutuhan akan Dokumen adalah 75. Dengan demikian siswa dinyatakan tuntas belajar jika memperoleh nilai $\geq 75$ atau dengan persentase $75 \%$ dan ketuntasan belajar secara klasikal ditetapkan jika persentase jumlah siswa yang tuntas belajar $\geq 85$ (KTSP SMK Negeri 1 Magetan, 2006).

Ketuntasan belajar seseorang dipengaruhi oleh faktor-faktor (a) bakat untuk mempelajari sesuatu, (b) mutu pengajaran, (c) kesanggupan untuk memahami pengajaran, (d) ketekunan, (e) waktu yang tersedia untuk belajar. (Nasution, 2003:50). Jika demikian, usaha apakah yang dapat dilakukan agar semua peserta didik memperoleh hasil belajar yang maksimal dan ketuntasan belajar dapat dicapai? Menurut pendapat Mulyasa (2006: 53) adalah “...pembelajaran harus dilaksanakan dengan sistematis. Kesistematisan akan tercermin dari strategi pembelajaran yang dilaksanakan, terutama dalam mengorganisir tujuan dan bahan belajar, melaksanakan evaluasi dan memberikan bimbingan terhadap peserta didik yang yang gagal mencapai tujuan yang ditetapkan."

\section{A. Kompetensi Dasar Memastikan Kebutuhan akan Dokumen}

\section{I n d ik a tor d a $\mathrm{n}$ a t e ri Pembelajaran}

Memastikan Kebutuhan akan Dokumen merupakan salah satu kompetensi dasar dari standar kompetensi Menghasilkan Dokumen Sederhana dan diajarkan di kelas XII program keahlian Administrasi Perkantoran SMK Negeri 1 Magetan 
pada semester ganjil tahun pelajaran 2010/2011. Indikator-indikator kompetensi dasar Memastikan Kebutuhan akan Dokumen mencakupi (1) tujuan dokumen, pembaca dan kebutuhan presentasi diklarifikasikan dengan pihak yang memiliki kewenangan sesuai peraturan organisasi atau perusahaan dan (2) mengenai kebutuhan organisasi yang berhubungan dengan surat menyurat dilaksanakan sesuai prosedur yang benar. Indikator tujuan dokumen, pembaca, dan kebutuhan presentasi diklarifikasikan dengan pihak yang memiliki kewenangan sesuai peraturan organisasi atau perusahaan, meliputi materi pembelajaran tentang (a) pengertian dokumen, (b) klasifikasi dokumen, (c) jenis-jenis dokumen, (d) format dokumen, (e) sumber dan produk dokumen,(f) fungsi dokumen (g) kebutuhan organisasi akan dokumen, (h) rancangan jumlah penerima dokumen, dan (i) kebutuhan akan bentuk-bentuk dokumen. Indikator mengenai kebutuhan organisasi yang berhubungan dengan surat menyurat dilaksanakan sesuai prosedur yang benar meliputi materi pembelajaran tentang (a) pengertian sistem surat menyurat,(b) macam-macam bentuk surat, dan (c) tata cara memproduksi dokumen berupa surat.

2. Ketuntasan Belajar Memastikan Kebutuhan akan Dokumen

Ketentuan mengenai ketuntasan belajar siswa pada komptensi dasar Memastikan Kebutuhan akan Dokumen didasarkan pada KKM yang telah ditetapkan yaitu sebesar 75 . Jadi siswa dinyatakan mencapai ketuntasan belajar untuk setiap bentuk penilaian yang dilakukan oleh guru pada kompetensi dasar Memastikan Kebutuhan akan Dokumen jika siswa memperoleh nilai $\geq 75$ atau dengan persentase ketercapaian $\geq 75 \%$, sedangkan untuk ketuntasan belajar secara klasikal ditetapkan jika persentase jumlah siswa yang tuntas belajar $\geq 85 \%$.

\section{B. Pembelajaran Kooperatif Model STAD}

Salah satu model di dalam pembelajaran kooperatif adalah pembelajaran dengan model STAD (Student Teams Achievement Divisions). Slavin (2008: 143) menyatakan "STAD merupakan salah satu metode pembelajaran kooperatif yang paling sederhana dan merupakan model yang paling baik untuk permulaan bagi para guru yang baru menggunakan pendekatan kooperatif."

Langkah-langkah pembelajaran kooperatif model STAD adalah (a) kelompokkan siswa masing-masing kelompok terdiri dari tiga sampai lima orang dengan anggota kelompok heterogen, (b) kegiatan pembelajaran dimulai dengan presentasi guru dalam menjelaskan berupa paparan masalah, pemberian data, pemberian contoh, (c) pemahaman konsep dilakukan dengan cara siswa diberi tugas-tugas kelompok, mereka mengerjakan secara kelompok atau saling bergantian, (d) siswa diberi tes atau kuis individu dan temantemannya tidak boleh menolong satu sama lain. Tujuannya untuk mengetahui kemampuan siswa, (e) hasil tes dibandingkan dengan rata-rata sebelumnya untuk mengetahui ketercapaian tingkat keberhasilan siswa atau melebihi kinerja sebelumnya. Kemampuan ini dijumlah untuk membentuk skor kelompok, setelah itu (f) guru memberi penghargaan kepada kelompok terbaik.

Hasil yang diharapkan dari pembelajaran kooperatif model STAD adalah memotivasi siswa untuk mendorong dan membantu satu sama lain dalam menguasai kompetensi-kompetensi yang disajikan oleh guru. Bila siswa menginginkan agar kelompok memperoleh penghargaan, maka mereka harus membantu kelompoknya untuk melakukan yang terbaik, bahwa belajar merupakan sesuatu yang menyenangkan, penting dan berharga. 


\section{Komponen Pembelajaran Model STAD}

Pembelajaran model STAD menekankan strategi belajar kelompok atau pembelajaran kooperatif (Cooperative Learning). Slavin (2008:143) membagi pembelajaran kooperatif model STAD menjadi lima komponen utama yaitu presentasi kelas, tim, kuis, skor kemajuan individual, dan rekognisi tim.

\section{a. Presentasi Kelas}

Materi dalam STAD pertamatama diperkenalkan dalam presentasi di dalam kelas dan benar-benar berrfokus pada unit STAD. Dengan cara ini para siswa akan menyadari bahwa mereka harus benar-benar member perhatian penuh selama presentasi kelas karena dengan demikian akan sangat membantu mereka mengerjakan kuis-kuis dan skor kuis mereka menentukan skor tim mereka (Slavin, 2008:144).

b. Tim

Tim terdiri dari empat atau lima siswa yang mewakili seluruh bagian dari kelas dalam hal kinerja akademik, jenis kelamin, ras dan etnisitas. Fungsi utama dari tim ini adalah memastikan bahwa semua anggota tim benarbenar belajar dan lebih khususnya lagi adalah untuk mempersiapkan anggotanya untuk bisa mengerjakan kuis dengan baik (Slavin, 2008:144).

\section{c. Kuis}

Setelah sekitar satu atau dua periode setelah guru memberikan presentasi dan sekitar satu atau dua periode praktik tim para siswa akan mengerjakan kuis individual. Para siswa tidak diperbolehkan saling membantu dalam mengerjakan kuis s ehingga tiap siswa bertanggungjawab secara individual untuk memahami materinya (Slavin,2008:144).

d. Skor Kemajuan Individual

Tiap siswa diberi skor awal. Selanjutnya siswa akan mengumpulkan poin untuk tim mereka berdasarkan tingkat kenaikan skor kuis mereka dibandingkan dengan skor awal mereka(Slavin,2008:146).

\section{e. Rekognisi Tim}

Tim akan mendapatkan sertifikat atau bentuk penghargaan yang lain apabila skor rata-rata mereka mencapai kriteria tertentu (Slavin,2008:146).

\section{Siklus Kegiatan Pembelajaran Kooperatif Model STAD}

\section{a. Mengajar}

Guru menyajikan pelajaran kepada siswa menggunakan presentasi verbal atau teks. Waktu 1 sampai 2 jam pelajaran untuk kegiatan pembukaan, pengembangan, dan latihan terbimbing.

b. Belajar dalam Tim atau Kelompok

Siswa dalam kelompok dengan anggota yang heterogen mengerjakan lembar kegiatan siswa. Guru memberikan lembar kerja siswa dan lembar jawaban pada masing-masing kelompok. Guru menekankan kepada siswa bahwa mereka belum selesai belajar sampai mereka yakin teman-teman satu kelompoknya dapat mencapai nilai 100 . Hal tersebut mengakibatkan siswa dalam satu kelompok harus berdiskusi saling membantu untuk menuntaskan materi belajar siswa yang lain. Mintalah semua anggota kelompok untuk membantu sebelum bertanya pada guru. Siswa dapat menggunakan buku pelajaran 
atau modul sebagai sumber belajar atau sebagai pendukung belajar. Sementara siswa bekerja dalam kelompok, guru berkeliling untuk mengamati kegiatan kelompok dan sebaiknya guru memuji kelompok yang semua anggotanya dapat bekerja dengan baik.

\section{c. Tes}

Secara mandiri atau individu setiap satu atau dua presentasi guru, siswa diberi kuis, d engan tujuan untuk menunjukkan apa saja yang telah diperoleh siswa selama belajar dalam kelompok. Bagikan kuis dan siswa diberi waktu yang cukup untuk menyelesaikannya. Pada saat mengerjakan, siswa tidak boleh saling membantu. Dalam hal ini siswa harus menunjukkan apa yang telah mereka pelajari secara individual. Siswa berpindah tempat duduk kalau memungkinkan. Hasil kuis digunakan sebagai skor perkembangan atau peningkatan individu dan disumbangkan dalam skor peningkatan kelompok. Slavin (2008:159) menjelaskan bahwa siswa mengumpulkan poin untuk tim mereka berdasarkan tingkat di mana skor kuis mereka (persentase yang benar) melampaui skor awal mereka.

$\mathrm{L}$ a n g k a h - 1 a n g k a h menentukan skor individu dijelaskan oleh Ibrahim (2000:56) sebagai berikut (1) menetapkan skor yaitu setiap siswa diberikan skor berdasarkan skor-skor kuis yang lalum (2) menghitung skor kuis terkini yaitu siswa memperoleh poin untuk kuis yang berkaitan dengan pelajaran terkini, dan (3) menghitung skor perkembangan atau peningkatan, yaitu siswa m e $n d a p$ a t k a $n$ p o i $n$ perkembangan yang besarnya ditentukan oleh skor kuis terkini, mereka menyamai atau melampaui skor mereka. Dapat juga menggunakan skala yang diberikan Slavin (2008:159) berikut ini:

\section{d. Penghargaan Kelompok}

Penghargaan kelompok ini ditempuh dengan langkahlangkah sebagai berikut:

1) Penentuan skor kelompok yaitu skor kelompok dihitung dengan menambahkan skor peningkatan tiap individu anggota kelompok dan membagi dengan jumlah kelompok yang hadir.

2) Penghargaan atas prestasi kelompok yaitu tiap kelompok menerima sertifikat khusus berdasarkan pada sistem poin berikut ini:

Rata-rata Kelompok

15 poin Penghargaan

$\begin{array}{ll}20 \text { poin } & \text { baik } \\ 25 \text { poin } & \text { Hebat }\end{array}$

Kriteria ini diprogram bahwa untuk menjadi kelompok hebat anggota kelompok harus mempunyai skor di atas skor dasar dan untuk menjadi kelompok super anggota kelompok harus mempunyai skor sekurang-kurangnya 10 poin di atas skor mereka. Kriteria tersebut dapat diubah bila dikehendaki. Penghargaan pada kelompok yang baik cukup dengan ucapan selamat atau sertifikat yang bentuknya kecil, sedangkan untuk kelompok hebat 
dan super dapat diberikan sertifikat yang lebih besar, menarik, dan berwarna cerah atau dengan memajang gambar pada papan pengumuman untuk kelompok tersebut. Gunakan imajinasi dan kreatifitas untuk mem-variasi penghargaan dari waktu ke waktu sehingga siswa merasa senang dan termotivasi untuk menyelesaikan tugas-tugas mereka dengan baik. Setiap periode penilaian, guru menghitung skor kuis rata-rata siswa dan menentukan skor dasar baru. Setelah 5 atau 6 minggu atau pada akhir periode penilaian, dibuat kelompok baru dengan tujuan memberi kesempatan baru pada siswa yang berada pada kelompok rendah untuk bekerja dengan teman yang lain. Laporan nilai harus berdasarkan pada skor kuis asli siswa, bukan pada peningkatan skor kelompok. Guru dapat memberikan bonus pada siswa yang memperoleh kelompok super. Laporan nilai ini dipisahkan dari skor kelompok mereka.

\section{METODE PENELITIAN}

\section{A. Rancangan Penelitian}

Penelitian ini direncanakan dalam tiga siklus. Setiap siklusnya terdiri dari empat tahap yaitu (1) perencanaan, (2) pelaksanaan, (3) pengamatan, dan (4) refleksi (Arikunto, 2007: 16). Dari data hasil refleksi siklus I akan dipergunakan sebagai acuan untuk menyusun perencanaan pada siklus II. Begitu pula dari data hasil refleksi siklus II akan dipergunakan sebagai acuan untuk menyusun perencanaan pada siklus III. Hal ini dimaksudkan untuk selalu mengadakan perbaikan pada setiap siklusnya sehingga tujuan dari penelitian ini dapat tercapai.

Rancangan penelitian untuk setiap siklusnya diuraikan sebagai berikut:

\section{Siklus I}

\section{a. Perencanaan:}

Kegiatan yang dilakukan pada tahap perencanaan siklus I ini adalah (1) menyusun silabus, (2) menyusun Rencana Pelaksanaan Pembelajaran (RPP) siklus I dengan menerapkan pembelajaraan kooperatif model STAD berdasarkan silabus,(3) menyusun daftar anggota kelompok berdasarkan skor dasar, (4) menentukan kriteria poin peningkatan individu dan kriteria penghargaan kelompok, (5) menyusun tabel kerja siklus I, (6) menyusun lembar kerja siswa, (7) menyusun instrumen tes siklus I, dan (8) menyusun lembar pengamatan kegiatan pembelajaran siklus I.

\section{b. Pelaksanaan}

Tahap pelaksanaan pada siklus I terdiri dari langkah-langkah penerapan pembelajaran kooperatif model Student Teams Achievement Divisions (STAD) sesuai dengan RPP siklus I yang telah dibuat. Pada saat kegiatan inti pembelajaran, guru melakukan langkah-langkah pembelajaran sebagai berikut (1) menyajikan materi pembelajaran, (2) mengumumkan daftar kelompok dengan jumlah anggota masingmasing kelompok sebanyak 5 orang dan meminta siswa untuk berkumpul sesuai dengan kelompoknya. (3) meminta kepada setiap kelompok memberi nama kelompoknya dengan nama-nama band favorit anggotanya, (4) membagikan lembar kerja siswa berupa daftar pertanyaan terkait dengan materi pada hari itu untuk didiskusikan dan dikerjakan dalam kelompok. Antar anggota di dalam kelompok saling membantu sehingga semua anggota memahami tentang materi yang didiskusikan, (5) membimbing siswa untuk membahas sekaligus mengoreksi pekerjaan kelompok secara bersama-sama, (6) meminta siswa kembali ke tempat duduk semula dan memberikan tes siklus I untuk dikerjakan secara 
individu dan tidak boleh saling membantu, (7) membimbing siswa untuk mengoreksi hasil tes siklus I secara bersama-sama, (8) memberikan penghargaan terhadap kelompok yang memperoleh rata-rata poin peningkatan anggota kelompok yang tertinggi dibanding dengan kelompok lainnya, (9) menyimpulkan materi pembelajaran bersama dengan siswa, dan (10) penutup.

\section{c. Pengamatan}

Pengamatan dilakukan bersamaan dengan kegiatan pembelajaran berlangsung. Petugas pengamat pada penelitian ini adalah Ibu Atik Wahyulis, S.Pd yang juga mengajar di kelas XII APk-1. Pengamatan dilakukan terhadap aktivitas guru dan siswa selama kegiatan pembelajaran. Caranya adalah pengamat mengisikan frekuensi pada setiap aspek pengamatan di lembar pengamatan dan menghitung persentasenya serta kategorinya. Selain itu, pengamatjuga memberikan catatan terhadap hal-hal yang menjadi temuan untuk melengkapi data hasil pengamatan.

\section{d. Refleksi}

Pada tahap ini tindakan yang telah dilakukan dikaji secara menyeluruh berdasarkan data hasil tes dan data hasil pengamatan yang telah terkumpul. Kemudian, dilakukan evaluasi dengan tujuan menyempurnakan tindakan pada siklus II.

\section{Siklus II}

a. Perencanaan:

Kegiatan yang dilakukan pada tahap perencanaan siklus II ini adalah melakukan perbaikan-perbaikan berdasarkan hasil refleksi siklus I. Hal-hal yang dilakukan adalah (1) menyusun Rencana Pelaksanaan Pembelajaran (RPP) siklus II dengan menerapkan pembelajaraan kooperatif model STAD berdasarkan silabus, (2) menyiapkan kriteria poin peningkatan individu dan kriteria penghargaan kelompok, (3) menyusun tabel kerja siklus II, (4) menyusun lembar kerja siswa, (5) menyusun instrumen tes siklus II, dan (6) menyusun lembar pengamatan kegiatan pembelajaran siklus II.

\section{b. Pelaksanaan}

Tahap pelaksanaan siklus II dilakukan berdasarkan RPP siklus II dengan menerapkan pembelajaran kooperatif model Student Teams Achievement Divisions (STAD). Pada saat kegiatan inti pembelajaran, guru melakukan langkah-langkah pembelajaran sebagai berikut (1) menyajikan materi pembelajaran, (2) meminta siswa untuk berkelompok seperti pada siklus I, (3) membagikan lembar kerja siswa berupa daftar pertanyaan terkait dengan materi pada hari itu untuk didiskusikan dan dikerjakan dalam kelompok. Antar anggota di dalam kelompok saling membantu sehingga semua anggota memahami tentang materi yang didiskusikan, (4) membimbing siswa untuk membahas sekaligus mengoreksi pekerjaan kelompok secara bersama-sama, (5) meminta siswa untuk kembali ke tempat duduknya semula dan memberikan tes siklus II untuk dikerjakan secara individu dan tidak boleh saling membantu, (6) membimbing siswa untuk mengoreksi hasil tes siklus II secara bersama-sama, (7) memberikan penghargaan terhadap k elompok yang anggota kelompoknya memperoleh rata-rata poin peningkatan tertinggi dibanding dengan kelompok lainnya, (8) menyimpulkan materi pembelajaran pada hari itu bersama dengan siswa, dan(9) penutup.

\section{c. Pengamatan}

Pengamatan dilakukan bersamaan dengan kegiatan pembelajaran berlangsung. Petugas 
pengamat pada siklus II ini adalah Ibu Atik Wahyulis, S.Pd. Pengamatan dilakukan dengan cara mengisi lembar pengamatan berupa frekuensi pada setiap aspek pengamatan serta menghitung persentase dan kategorinya. Selain itu, pengamat juga memberikan catatan terhadap hal-hal yang menjadi temuan untuk melengkapi data hasil pengamatan.

\section{d. Refleksi}

Pada tahap ini tindakan yang telah dilakukan dikaji secara menyeluruh berdasarkan data hasil tes dan data hasil pengamatan yang telah terkumpul untuk mengetahui letak keberhasilan dan hambatan dari tindakan yang telah dilakukan. Kemudian, dilakukan evaluasi dengan tujuan menyempurnakan tindakan pada siklus III.

\section{Siklus III}

\section{a. Perencanaan:}

Kegiatan yang dilakukan pada tahap perencanaan siklus III ini adalah melakukan perbaikan-perbaikan berdasarkan hasil refleksi siklus II. Hal-hal yang dilakukan pada tahap perencanaan siklus III ini adalah (1) menyusun Rencana Pelaksanaan Pembelajaran (RPP) siklus III dengan menerapkan pembelajaraan kooperatif model STAD, (2) menyiapkan kriteria poin peningkatan individu dan kriteria penghargaan kelompok, (3) menyusun tabel kerja, (3) menyusun lembar kerja siswa, (4) menyusun instrumen tes siklus III, (5) menyusun lembar pengamatan kegiatan pembelajaran siklus III, dan (6) menyusun angket penerapan pembelajaran koooperatif model STAD.

\section{b. Pelaksanaan}

Kegiatan pembelajaran siklus III dilaksanakan berdasarkan RPP siklus III dengan menerapkan pembelajaran kooperatif model Student Teams Achievement
Divisions (STAD) yang telah diperbaiki berdasarkan hasil refleksi pada siklus II. Pada saat kegiatan inti pembelajaran, guru melakukan langkah-langkah pembelajaran sebagai berikut (1) menyajikan materi pembelajaran, (2) meminta siswa untuk berkelompok seperti pada siklus I dan II, (3) membagikan lembar kerja siswa berupa daftar pertanyaan terkait dengan materi pada hari itu untuk didiskusikan dan dikerjakan dalam kelompok. Antar anggota di dalam kelompok saling membantu sehingga semua anggota memahami tentang materi yang didiskusikan, (4) membimbing siswa untuk membahas sekaligus mengoreksi pekerjaan kelompok secara bersama-sama, (5) meminta siswa untuk kembali ke tempat duduknya semula dan memberikan tes siklus III untuk dikerjakan secara individu dan tidak boleh saling membantu, (6) membimbing siswa untuk mengoreksi hasil tes siklus III secara bersama-sama, (7) memberikan penghargaan terhadap kelompok yang anggota kelompoknya memperoleh rata-rata poin peningkatan tertinggi dibanding dengan kelompok lainnya, (8) menyimpulkan materi pembelajaran pada hari itu bersama dengan siswa (9) membagikan angket kepada siswa, dan (10) penutup.

\section{c. Pengamatan}

Pengamatan dilakukan bersamaan dengan kegiatan pembelajaran berlangsung. Petugas pengamat pada siklus III ini adalah Ibu Atik Wahyulis, S.Pd. Pengamatan dilakukan terhadap aktivitas guru dan siswa selama kegiatan pembelajaran. Pengamatan dilakukan dengan cara mengisi lembar pengamatan berupa frekuensi pada setiap aspek pengamatan serta menghitung persentase dan kategorinya. Selain itu, pengamat juga memberikan catatan 
terhadap hal-hal yang menjadi temuan untuk melengkapi data hasil pengamatan.

\section{d. Refleksi}

Pada tahap refleksi, data hasil tes, data hasil pengamatan siklus III dan data hasil angket dianalisis. Setelah itu, dilakukan evaluasi dan hasilnya dijadikan sebagai dasar melakukan refleksi untuk mengungkapkan tingkat keberhasilan tindakan pada siklus III dan kekurangan yang mungkin masih terjadi.

\section{B. Subyek dan Setting Penelitian}

Subyek penelitian ini adalah siswa kelas XII APk-1 SMK Negeri 1 Magetan yang berjumlah 35 orang, terdiri dari 34 siswa wanita dan 1 siswa laki-laki pada saat mereka mengikuti jam pembelajaran kompetensi dasar Memastikan Kebutuhan akan Dokumen. Alasan yang mendasari penelitian ini dikenakan pada kelas tersebut adalah dari data hasil tes yang dilakukan sebelum tindakan menunjukkan bahwa ketuntasan belajar secara klasikal belum tercapai yaitu hanya sekitar $31.43 \%$ dan siswa kurang aktif dalam kegiatan belajar kelompok.

Penelitian ini dilakukan oleh Dra. Arum Yuliani yang berstatus sebagai guru mata pelajaran di Program Keahlian Administrasi Perkantoran SMK Negeri 1 Magetan dan sekaligus bertindak sebagai guru saat tahap pelaksanaan tindakan di kelas. Peneliti dibantu oleh teman sejawat yang juga mengajar di Program Keahlian Administrasi Perkantoran SMK Negeri 1 Magetan yaitu Atik Wahyulis, S.Pd yang bertugas sebagai pengamat.

\section{Teknik dan Instrumen Pengumpulan Data}

Teknik pengumpulan data yang digunakan dalam penelitian ini adalah tes dan nontes. Sedangkan instrumen pengumpulan datanya berupa soal tes buatan guru, lembar pengamatan, dan angket.

\section{Tes}

Tes yang digunakan dalam penelitian ini adalah tes buatan guru yang diberikan di setiap siklus. Tujuannya untuk mengetahui ketuntasan belajar siswa dalam bidang kognitif setelah mengikuti kegiatan pembelajaran kooperatif model STAD. Ketuntasan belajar yang diukur dalam penelitian ini terdiri dari ketuntasan belajar secara individu dan klasikal. Siswa dinyatakan tuntas belajar secara individu jika siswa memperoleh nilai $\geq 75$ atau dengan persentase $\geq 75 \%$ dan kelas dinyatakan tuntas jika persentase jumlah siswa yang tuntas belajar $\geq 85 \%$ (KTSP SMK N 1 Magetan, 2006).

2. Nontes

Teknik nontes digunakan untuk memperoleh data aktivitas siswa dan guru serta pendapat siswa terhadap penerapan pembelajaran kooperatif model STAD. Instrumen nontes yang dipergunakan dalam penelitian ini adalah lembar pengamatan kegiatan pembelajaran dan angket penerapan pembelajaran kooperatif model STAD.

\section{a. Lembar Pengamatan}

Lembar pengamatan kegiatan pembelajaran digunakan oleh pengamat untuk mendata hasil pengamatan. Hal yang diamati adalah aktivitas guru dan siswa selama dilaksanakannya pembelajaran kooperatif model STAD. Waktunya bersamaan dengan berlangsungnya kegiatan pembelajaran pada siklus I, siklus II, dan siklus III. Pada saat mengamati, pengamat juga memberikan catatan terhadap apa yang terjadi untuk mendapatkan data yang akurat untuk memperbaiki siklus berikutnya (Arikunto, 2007: 19).

Pengamatan terhadap aktivitas siswa yang dimaksud dalam penelitian ini adalah aktivitas siswa dalam mengikuti langkah-langkah atau tahapan-tahapan kegiatan pembelajaran kooperatif model STAD yang diterapkan oleh guru. Ada 8 
aspek pengamatan terhadap aktivitas siswa yaitu (1) mendengarkan / memperhatikan penjelasan guru, (2) mengikuti langkah-langkah/tahapan pembelajaran sesuai dengan arahan dari guru, (3) aktif bertanya/ menjawab/berpendapat tentang materi pelajaran, (4) aktif bekerjasama dalam kegiatan kelompok/tim, (5) membuat catatan penting tentang materi pelajaran, (6) mandiri dalam mengerjakan tes, (7) mengumpulkan tugas tepat waktu, dan (8) antusias dalam kegiatan pembelajaran. Pengamat bertugas mengisikan frekuensi pada setiap aspek dan menghitung persentasenya serta menentukan kategorinya.

Pengamatan terhadap aktivitas guru yang dimaksud dalam penelitian ini adalah aktivitas guru dalam menerapkan pembelajaran kooperatif model STAD.

Dalam hal ini pengamat cukup mencatat hal-hal yang menjadi temuan pada saat kegiatan pembelajaran berlangsung dengan tujuan untuk melengkapi data hasil pengamatan.

b. Angket

A n g k e t p e n e r a p a n pembelajaran kooperatif model STAD diberikan kepada siswa dengan tujuan untuk mengetahui respon mereka terhadap penerapan pembelajaran kooperatif model STAD. Angket ini diberikan sebanyak satu kali yaitu di akhir pelaksanaan kegiatan pembelajaran pada siklus III.

\section{Teknik Analisis Data}

Pengolahan terhadap data yang terkumpul pada penelitian ini bertujuan menghasilkan suatu kesimpulan yang dapat dipertanggungjawabkan. Teknik analisis data yang digunakan dengan cara analisis data kuantitif pada hasil tes yang dikerjakan siswa dan analisis data kualitatif pada hasil pengamatan kegiatan pembelajaran dan angket siswa.
1. Data hasil Tes

a. Nilai Individu

b. Persentase Ketercapaian Nilai Individu

c. Ketuntasan Belajar

2. Data Hasil Nontes

a. Data Hasil Pengamatan

Besaran frekuensi yang diberikan pengamat pada 8 aspek pengamatan terhadap aktivitas siswa. Berdasarkan persentase, maka pengamat menentukan kategori aktivitas siswa pada setiap aspeknya dengan ketentuan sebagai berikut:

b. Data Hasil Angket

Data hasil angket diperoleh dari menghitung frekuensi jawaban siswa yang menyatakan "ya" dan "tidak" terhadap lima petanyaan yang terdapat pada angket penerapan pembelajaran kooperatif model STAD.

\section{E. Indikator Keberhasilan}

Indikator keberhasilan yang ditetapkan dalam penelitian ini adalah :

1. Siswa dinyatakan tuntas belajar secara individu jika nilai yang diperoleh siswa $\geq 75$ atau dengan persentase $\geq 75 \%$.

2. Ketuntasan belajar secara klasikal tercapai jika persentase jumlah siswa yang tuntas belajar secara individu $\geq$ $85 \%$ dari jumlah siswa yang mengikuti tes.

3. Aktivitas siswa dibagi dalam empat kategori yaitu:

\section{F. Jadwal Penelitian}

Penelitian ini dilaksanakan pada semester ganjil pada bulan september sampai dengan November tahun pelajaran 2010/2011

\section{HASIL DAN PEMBAHASAN}

Penelitian ini dilakukan pada siswa kelas XII Program Keahlian Administrasi Perkantoran-1 (XII APk-1) semester ganjil tahun pelajaran 2010/2011. Jumlah siswa di kelas ini sebanyak 35 orang yang terdiri dari 34 orang perempuan dan 1 orang laki-laki . 
Lokasi penelitiannya di SMK Negeri 1 Magetan, Jalan Kartini 6 Magetan.

Secara umum prestasi akademis siswa di kelas tersebut tergolong kurang merata. Ada sebagian kecil siswa dengan prestasi akademis yang sangat tinggi tetapi sebagian besar yang lain dengan prestasi akademis yang sangat rendah. Demikian pula tentang tingkah laku siswa saat mengikuti pembelajaran, ada sebagian kecil siswa yang aktif tetapi sebagian besar yang lain cenderung kurang aktif.

Alasan penelitian ini dikenakan pada kelas tersebut adalah ketuntasan belajar siswa tergolong rendah dan siswa kurang aktif dalam kegiatan belajar kelompok. Berdasarkan data hasil pengamatan pada saat kegiatan pembelajaran dengan materi ergonomi dan sumber daya alam dan energi, diketahui bahwa siswa kurang aktif dalam kegiatan belajar kelompok. Jika kelompok beranggotakan 5 orang, maka yang aktif untuk mengerjakan tugas kelompok hanya sekitar 2 orang. Bahkan ada juga kelompok yang didominasi oleh satu orang saja. Hal itu mengakibatkan hasil pekerjaan kelompok menjadi kurang maksimal dan hanya sebagian kecil saja siswa yang memahami materi tugas kelompok.

Adapun data hasil tes sebelum tindakan yang dilakukan pada kelas tersebut menunjukkan, bahwa jumlah siswa yang tuntas belajar hanya 11 orang dan ketuntasan belajar secara klasikal rendah karena hanya memperoleh persentase sebesar $31.43 \%$ atau belum mencapai ketuntasan yang ditetapkan yaitu $\geq 85 \%$ (KTSP SMK N 1 Magetan, 2006).

\section{PEMBAHASAN}

Permasalahan yang ditemui peneliti ketika mengajar kompetensi dasar Memastikan Kebutuhan akan Dokumen di kelas XII Apk-1 SMK Negeri 1 Magetan pada semester ganjil tahun pelajaran 2010/2011 adalah ketuntasan belajar secara klasikal rendah dan siswa kurang aktif dalam kegiatan belajar kelompok. Berdasarkan data hasil tes sebelum tindakan, menunjukkan bahwa ketuntasan belajar secara klasikal belum tercapai karena hanya memperoleh persentase sebesar $31.43 \%$, sedangkan data hasil pengamatan menunjukkan bahwa siswa tidak dapat bekerja sama secara efektif dalam kelompok. Mereka cenderung memboroskan waktu dengan berbicara di luar materi pelajaran, mengerjakan tugas tidak bersungguh-sungguh, bahkan ada juga siswa yang diam saja. Di sisi lain ada kelompok yang didominasi oleh satu orang saja. Akibatnya siswa kurang memahami materi tugas kelompok.

Setelah dilakukan evaluasi terhadap permasalahan tersebut, maka peneliti mengakui bahwa guru kurang maksimal dalam mengelola pembelajaran secara berkelompok. Misalnya, guru kurang telaten di dalam memberikan bimbingan kepada siswa ketika sedang bekerja dalam kelompok, guru kurang memotivasi siswa, guru tidak melakukan penilain terhadap aktivitas individu dalam kelompok, guru bersikap kurang tegas, guru kurang memberikan penghargaan terhadap hasil kerja kelompok atau justru guru meninggalkan kelas pada saat siswa mengerjakan tugas kelompok. Oleh karena itu penelitian ini didesain dengan model penelitian tindakan kelas karena bertujuan untuk memperbaiki pengelolaan pembelajaran sehingga permasalahan yang timbul dapat dicarikan solusinya. Adapun perbaikan yang dimaksudkan dalam penelitian ini adalah dengan menerapkan pembelajaran kooperatif model STAD.

Dalam penelitian ini, data mengenai ketuntasan belajar siswa diperoleh dari hasil tes yang dilaksanakan pada siklus I, siklus II, dan siklus III. Siswa dinyatakan tuntas belajar jika siswa memperoleh nilai yang sama atau melebihi KKM yang ditetapkan yaitu sebesar 75. Jadi siswa dinyatakan tuntas belajar secara individu jika nilai siswa $\geq 75$ atau dengan persentase $\geq 75 \%$. Bila siswa mendapatkan nilai dibawah 75 maka siswa dikatakan belum tuntas belajar. Sedangkan ketuntasan belajar secara klasikal tercapai jika persentase jumlah siswa yang tuntas belajar $\geq 85 \%$. 
Pengamatan dalam penelitian ini dilakukan bersamaan dengan kegiatan pembelajaran berlangsung. Untuk memperoleh data pengamatan dipergunakan lembar pengamatan kegiatan pembelajaran. Pengamatan terhadap aktivitas siswa dilakukan dengan cara menghitung frekuensi dan persentase masing-masing aspek pengamatan yang sudah dicantumkan ke dalam lembar pengamatan. Berdasarkan persentase ini ditentukan kategori untuk aktivitas siswa. Pengamat membuat catatan terhadap hal-hal yang dilakukan oleh guru saat menerapkan pembelajaran kooperatif model STAD. Apakah hal-hal yang dilakukan sudah mendukung atau kurang mendukung terhadap keberhasilan penerapan pembelajaran kooperatif model STAD. Setelah itu dilakukan evaluasi terhadap hasil pengamatan untuk menentukan bentukbentuk tindakan perbaikan terhadap kekurangan-kekurangan yang terjadi dan mempertahankan hal yang positip yang akan dilaksanakan pada siklus berikutnya.

Untuk mengetahui respon siswa terhadap penerapan pembelajaran kooperatif model STAD, maka pada siklus III dibagikan angket yang berisikan lima pertanyaan yang terkait dengan pendapat siswa tentang penerapan pembelajaran kooperatif model STAD. Siswa diberi alternatif jawaban "ya" jika ia setuju dan jawaban "tidak" jika ia tidak setuju terhadap pertanyaan tersebut.

Berdasarkan hasil penelitian pada siklus I, siklus II, dan siklus III diperoleh temuan-temuan sebagai berikut:

1. Data Hasil Tes Siklus I, Siklus II, dan Siklus III

Distribusi hasil tes siklus I, siklus II, dan siklus III disajikan dalam bentuk tabel sebagai berikut:

Tabel 4.16 Distribusi Hasil Tes Siklus I,Siklus II, dan Siklus III

\begin{tabular}{clccc}
\hline No. & \multicolumn{1}{c}{ Aspek Hasil } & Siklus I & Siklus II & Siklus III \\
\hline 1. & Jumlah siswa Tuntas Belajar & 26 & 31 & 35 \\
2. & Jumlah siswa Tidak Tuntas Belajar & 9 & 4 & 0 \\
3. & $\%$ Ketuntasan Belajar Klasikal & $74.29 \%$ & $88.57 \%$ & $100 \%$ \\
\hline
\end{tabular}

Bila digambarkan dalam bentuk histogram maka hasil tes siswa tampak sebagai berikut:

Gambar 4.1 Histogram Distribusi Hasil Tes Siklus I, Siklus II, dan Siklus III

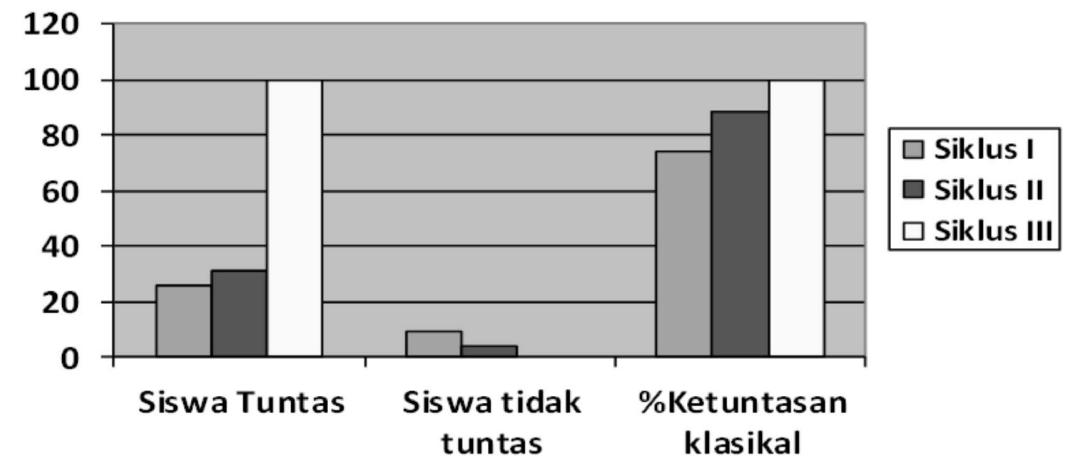


Berdasarkan data pada tabel dan gambar histogram di atas, menunjukkan bahwa ada peningkatan untuk jumlah siswa yang tuntas belajar pada setiap siklusnya. Pada siklus I jumlah siswa yang tuntas belajar sebanyak 26 siswa dan pada siklus II meningkat menjadi 31 siswa. Bahkan pada siklus III seluruh siswa dinyatakan telah tuntas belajar.

Persentase ketuntasan belajar secara klasikal juga mengalami peningkatan pada setiap siklusnya yaitu pada siklus I sebesar $74.29 \%$ meningkat menjadi $88.57 \%$ pada siklus II dan pada siklus III menjadi 100\%. Sedangkan jumlah siswa yang tidak tuntas belajar mengalami penurunan pada setiap siklusnya yaitu pada siklus I sebanyak 9 siswa, siklus II sebanyak 4 siswa dan pada siklus III tidak ada siswa yang tidak tuntas belajar.

\section{Data Hasil Pengamatan Siklus I, Siklus II, dan Siklus III}

Data hasil pengamatan terhadap aktivitas siswa menunjukkan bahwa frekuensi, persentase, dan kategori untuk setiap aspek pengamatan pada setiap siklusnya mengalami peningkatan.

a. Aktivitas mendengarkan dan memperhatikan penjelasan guru pada siklus I frekuensinya sebesar 26, pada siklus II meningkat menjadi 30 dan pada siklus III mencapai 35. Jika dipersentase hasilnya $74.29 \%$ pada siklus I, $85.71 \%$ pada siklus II dan $100 \%$ pada siklus III atau meningkat sekitar $11 \%$ sampai dengan $14 \%$. Demikian pula kategori pada siklus I termasuk kurang, siklus II dan siklus III menjadi Amat Baik.

b. Aktivitas mengikuti langkahlangkah/tahapan pembelajaran sesuai dengan arahan dari guru pada siklus I frekuensinya sebesar 18, pada siklus II meningkat menjadi 28 dan pada siklus III mencapai 35. Jika dipersentase hasilnya $51.43 \%$ pada siklus I, $80 \%$ pada siklus II dan $100 \%$ pada siklus III atau meningkat sekitar 20\% sampai dengan $29 \%$. Demikian pula kategori pada siklus I termasuk kurang, siklus II Baik dan siklus III menjadi Amat Baik.

c. Aktivitas bertanya/menjawab/ berpendapat tentang materi pelajaran pada siklus I frekuensinya sebesar 10, pada siklus II meningkat menjadi 18 dan pada siklus III mencapai 25. Jika dipersentase hasilnya $28.57 \%$ pada siklus I, $51.43 \%$ pada siklus II dan $71.43 \%$ pada siklus III atau meningkat sekitar 11\% sampai dengan $20 \%$. Demikian pula kategori pada siklus I dan siklus II termasuk kategori Kurang dan siklus III menjadi kategori Baik.

d. Aktivitas bekerjasama dalam kegiatan kelompok/tim pada siklus I frekuensinya sebesar 12 , pada siklus II meningkat menjadi 28 dan pada siklus III mencapai 30. Jika dipersentase $34.29 \%$ pada siklus I, $80 \%$ pada siklus II dan $85.71 \%$ pada siklus III atau meningkat sekitar $16 \%$ sampai dengan 46\%. Demikian pula kategori pada siklus I termasuk kategori Kurang, siklus II Baik dan siklus III menjadi Amat Baik.

e. Aktivitas membuat catatan penting tentang materi pelajaran pada siklus I frekuensinya sebesar 20 , pada siklus II meningkat menjadi 26 dan pada siklus III mencapai 35. Jika dipersentase $57.14 \%$ pada siklus I, $74.29 \%$ pada siklus II dan $100 \%$ pada siklus III atau meningkat sekitar 17\% sampai dengan $26 \%$. Demikian pula kategori pada siklus I termasuk kategori Kurang, siklus II Baik dan siklus III menjadi Amat Baik.

f. Aktivitas mandiri dalam mengerjakan tes pada siklus I frekuensinya sebesar 21, pada siklus II meningkat menjadi 30 dan pada siklus III mencapai 35 . Jika dipersentase $60 \%$ pada siklus I, $85.71 \%$ pada siklus II dan $100 \%$ pada siklus III atau meningkat sekitar 14\% sampai dengan $26 \%$. Demikian pula kategori pada siklus I termasuk 
kategori Kurang, siklus II dan siklus III menjadi Amat Baik.

g. Aktivitas mengumpulkan tugas tepat waktu pada siklus I frekuensinya sebesar 26, pada siklus II meningkat menjadi 30 dan pada siklus III mencapai 35. Jika dipersentase $62.86 \%$ pada siklus I, $85.71 \%$ pada siklus II dan $100 \%$ pada siklus III atau meningkat sekitar $14 \%$ sampai dengan 23\% . Demikian pula kategori pada siklus I termasuk kategori Kurang, siklus II dan siklus III menjadi Amat Baik.

h. Antusias dalam kegiatan pembelajaran pada siklus I frekuensinya sebesar 20, pada siklus II meningkat menjadi 32 dan pada siklus III mencapai 35. Jika dipersentase $57.14 \%$ pada siklus I, $91.43 \%$ pada siklus II dan $100 \%$ pada siklus III. Meningkat sekitar 8\% sampai dengan $35 \%$. Kategori pada siklus I termasuk kurang, siklus II dan siklus III menjadi Amat Baik.

\section{Data Hasil angket}

Penerapan pembelajaran kooperatif model STAD mendapatkan respon yang positip dari siswa untuk setiap aspek yang ditanyakan yaitu:

a. Semua siswa senang dan terdorong untuk lebih rajin belajar jika guru menerapkan pembelajaran kooperatif model STAD.

b. Sebanyak 32 orang siswa menyatakan bahwa penerapan pembelajaran kooperatif model STAD cocok untuk materi pelajaran pada kompetensi dasar Memastikan Kebutuhan akan Dokumen. Sebaliknya 3 orang siswa yang lain menyatakan tidak cocok.

c. Sebanyak 30 orang siswa menyatakan lebih mudah memahami materi pelajaran pada kompetensi dasar Memastikan Kebutuhan akan Dokumen tetapi 5 orang siswa yang lain menyatakan tidak.

d. Sebanyak 28 orang siswa menyatakan terdorong untuk aktif dalam kegiatan pembelajaran kooperatif model STAD dan 7 orang siswa yang lain menyatakan tidak

\section{PENUTUP \\ Simpulan}

Berdasarkan hasil penelitian yang telah dipaparkan dalam tiga siklus, hasil seluruh analisis dan pembahasan yang telah dilakukan, peneliti menyimpulkan bahwa:

1. Penerapan pembelajaran kooperatif model STAD dapat meningkatkan ketuntasan belajar memastikan kebutuhan akan dokumen pada siswa kelas XII APk-1 SMK Negeri 1 Magetan pada tahun pelajaran 2010/2011.

2. Penerapan pembelajaran kooperatif model STAD dapat meningkatkan aktivitas belajar kelompok dalam memastikan kebutuhan akan dokumen pada siswa kelas XII APk-1 SMK Negeri 1 Magetan pada tahun pelajaran 2010/2011.

3. Penerapan pembelajaran kooperatif model STAD menyenangkan dan dapat mendorong siswa kelas XII APk-1 SMK Negeri 1 Magetan pada tahun pelajaran 2010/2011 untuk rajin belajar pada kompetensi dasar Memastikan Kebutuhan akan Dokumen.

\section{Saran}

Berdasarkan simpulan di atas, maka peneliti menyarankan:

1. Ketuntasan belajar siswa adalah salah satu tujuan yang harus dicapai oleh guru sehingga guru harus lebih cermat dalam memilih metode maupun model pembelajaran yang sesuai dengan materi pelajaran, indikator, kompetensi dasar, dan standard kompetensi dari mata pelajaran yang diampunya. Caranya dengan menerapkan berbagai macam model atau metode pembelajaran yang bervariasi dan inovatif. Hal ini untuk menghindari rasa bosan siswa terhadap satu model atau metode pembelajaran tertentu.

2. Untuk mencapai ketuntasan belajar siswa secara maksimal, salah satu yang diharapkan dilakukan oleh guru adalah mengelola pembelajarannya dengan baik agar siswa lebih aktif dalam kegiatan pembelajaran sehingga mereka akan lebih 
mudah memahami materi pelajaran. Guru harus menyusun Rencana Pelaksanaan Pembelajaran (RPP) secara matang dan dilaksanakan dengan penuh disiplin dan tanggung jawab.

\section{DAFTAR PUSTAKA}

Arikunto, Suharsimi. (2007). Penelitian Tindakan Kelas. Jakarta: Bumi Aksara.

Boyke, Paath, et al. (1995). Manajemen Perkantoran 2. Bandung: Angkasa.

Depdiknas. 2004. Kurikulum SMK Edisi 2004 Bidang Keahlian Bisnis dan Manajemen Program Keahlian Administrasi Perkantoran. Direktorat Jenderal Pendidikan Dasar dan Menengah, Direktorat Menengah Kejuruan.
Anita Lie. (2007). Cooperatif Learning, Mempraktikan Cooperatif Learning di Kelas-Kelas. Jakarta: PT Gramedia.

Madiana, et al. (1996). Manajemen Perkantoran SMK. Bandung: Armico.

Majid, abdul. (2008). Perencanaan Pembelajaran. Bandung. PT Remaja Rosdakarya.

Mulyasa, E. (2006). Kurikulum Berbasis Kompetensi, Konsep, Karakteristik, dan Implementasi. Bandung: PT Remaja Rosdakarya.

Slameto. (2001). Proses Belajar Mengajar. Jakarta: Bumi Aksara.

Slavin, Robert E. (2008). Terjemahan Cooperatif Learning, Theory, Research and Practice. Bandung: Nusa Media. 